ever may have been the case in the past, it will not have to contend against that love for 'the thing which has been' which in all periods of history has afforded a distinguishing characteristic of the average official intelligence. In a nation of sailors and yachtsmen a suggestion for the improvement of lighthouses and for the greater safety of shipping ought to be certain of speedy and complete consideration upon its merits alone."

\section{THE TURKOMANS}

$\Delta \mathrm{T}$ the meeting of the Anthropological Institute on November 23 , there was read a short but suggestive paper on these way ward children of the desert, contributed by Prof. Arminius Vambery. The learned writer, who has perhaps as great a personal knowledge of Eastern nations as any man living, regarded the Turkomans as on the whole the purest and most representative branch of the widespread Tûrki family and described their outward features as quite distinct from the Mongolian. His account was somewhat vague, but the inference evidently was that they belonged in his opinion ethnically to the Caucasian rather than to the Mongolian group. Nor did he attribute this to the gradual absorption of Iranian elements, but, on the contrary, stated that intermarriages with Persian women were much less frequent than is usually supposed, and that the Turkomans are now what they always have been, men of medium stature, like the Kirghizes and unlike the Usbegs and Osmanlis, amongst whom tall individuals are far from rare, with straight or but very slightly oblique ("almond-shaped") eyes, handsome regular features and fair complexion. He further stated that the Turkoman language was also one of the very purest Tûrki tongues still spoken, so much so, that an ordinary Seljukian Turk of Asia Minor would have less difficulty in conversing with a Tekke or Yomut Turkoman than with his nearer neighbours the Turki nomads of Azarbijan and other parts of Persia. In fact, such is the purity of their speech, that the Rev. Janies Bassett, of the American Mission at Tehrân, is now putting through the press in London his translation of St. Matthew's Gospel in the Jagatai Tûrki for the special use of the Tekke Turkomans. Jagatai, it need scarcely be remarked, is one of the most cultivated of all the Tartar tongues and is still current in Bokhara, Khiva, Ferghana, and parts of Kashgaria. In it are written the Emperor Baber's memoirs, and being less affected by Arabic and Persian elements than the Osmanli of Constantinople, it may be taken as, on the whole, the most representative of Tûrki idioms. On the other hand, the Tûrki belongs undoubtedly to the same great linguistic connection as the Mongolian, both being recognised by modern philologists as collateral, though independent, members of the so-called Finno-Tataric or Ural-Altaic family of languages. Hence Vambery's description of the physical characteristics of the Turkoman race places them in a sufficiently anomalous position from the anthropological point of view, in so far as they would seem to belong ethnically to the Caucasian, but linguistically to the Mongol stock. Such anomalies are, no doubt, common enough, and instances abound of peoples having changed their language and adopted that of the races by whom they may have been subdued or otherwise influenced. But in the present case the difficulty cannot be got over in this way, nor is it pretended that the Turkomans have adopted a Mongolian form of speech, or indeed that they ever spoke any other language than Tûrki. But Tûrki and Mongolian being offshoots of the same organic tongue, it follows that both races must have had a common origin, and that the Turkomans have since become differentiated from the ethnical, while retaining the linguistic connection. Now this is entirely at variance with the commonly-accepted doctrine that physical traits are always more persistent than speech, in other words that, assuming absolute isolation, the process of linguistic will always be more rapid than that of racial evolution.

In the abstract this is no doubt true enough, but practically there is no such thing as absolute isolation in the present stage of the world's history. Least of all can it be predicated of the Turkomans, who are intruders from the east or north-east in their present habitat, who must have absorbed far more Iranian blood than Vambery is inclined to admit, and who, instead of being the purest representatives of the Turki race, seem really to be a mongrel people, the outcome of fusion of Mongolian and Caucasian elements in Hyrcania, Bactriana, and the Lower Oxus basin. It must be remembered that the whole of this region, as far north at least as the 4oth parallel, formed an integral part of the ancient Persian Empire, ard the presence of numerous Iranian communities still speaking Persian dialects both in the lowlands and highlands of Turkestan (Tajiks and Galchas) suffciently proves that this region was fairly occupied by peoples of Iranian stock, if, indeed, it was not their primitive home, before the arrival of the Turki race driven still westwards by the Mongolians of the Gobi. When the Persian power was finally broken by the Arabs, Turki hordes easily took permanent possession of the Atrek and Murghab Valleys, as well as of the Lower Oxus; but in so doing they gradually absorbed as much Iranian blood as to have in course of time become largely assimilated to the Caucasian type. The same fate overtook their Seljukian brethren in Asia Minor and the Balkan peninsula, all of whom have everywhere become largely Aryanised, and have thus collectively contributed to produce the impression, shared by Vamberry with many ethnologists, that the Tûrki and Mongol types were originally distinct. They themseves bave always rightly looked on each other as brethren, and although no importance can be attached to the tradition of a legendary Tûrk, son of Japhet, whence both sprang through the twin brothers Tatar and Mongol, it nevertheless points, like so many other national myths, at a fundamental truth.

Nor are the Mongolian traits so far effaced from the Turkoman race as Vambéry would have us suppose. In "Clouds in the East" Valentine Baker, an equally careful observer, describes them as "muscular, heavy-limbed men, with large hands, rather flat, broad faces, and small eyes, thus showing much of the Tatar type" (p. 2 r2). He even expresses his surprise that it should still be so distinctly marked, "as they constantly capture Persian girls, who become their wives, and so must bring a strong infusion of Persian blood into the race" $(i b$.$) .$

The genuine Tûrki type, however, is still best exhibited in the Kazaks, or, as they are more frequently called, the Kirghizes and Kara-Kirghizes of the West Siberian steppes and Pamir table-land. These Kirghizes speak a pure Tûrki dialect, and because of their distinctly Mongolian features-square, flat face, high cheek bones, oblique eyes, large mouth, \&c. - they are supposed to be Mongolised Tatars by those who hold the two types to be originally distinct. But the supposition is entirely gratuitous, and although they may have been to some extent affected by Mongolian elements during the incessant migrations of the Central and Eastern Asiatic nations, there is nothing in their appearance to imply any profound modification of their outward features, while their Tûrki speech militates against the assumption. They resemble the Mongolians because both were originally one, and because in their present homes between Kulja and the Ural Mountains they came in contact with no foreign elements by which the race could be seriously affected. In the Kirghizes we therefore recognise a living proof of the primordial identity of Turk and Mongol.

The transition between the Kirghizes and Turkomans is formed by the Kipchaks of Khokand and other parts of Eastern Turkestan, who, though often classed with the 
Mongolian Buryats, ${ }^{1}$ are of the genuine Tûrki stock, and speak a pure Tûrki language, though rude and marked by some distinct features.

Touching the numbers and strength of the Turkoman tribes proper, opinions vary considerably. While Behm and Wagner reckon them at no more than 450,000, Vambéry still adheres to the number of one million given in his "Travels in Central Asia," adding that further research may tend to increase, but certainly not to diminish that figure. This estimate is partly borne out by Gen. Obrutcheff, 2 who makes them amount in 1874 altogether to about 930,000, exclusive of the "Eski-Turk" and other scattered members of the family in Asia Minor, North Syria, the Euphrates Valley, and Persia.

In view of recent and pending political events, the subjoined list of the Turkoman tribes with their localities and approximate numbers may be acceptable:-

\begin{tabular}{|c|c|c|}
\hline Tribe. & Population. & Locality. \\
\hline 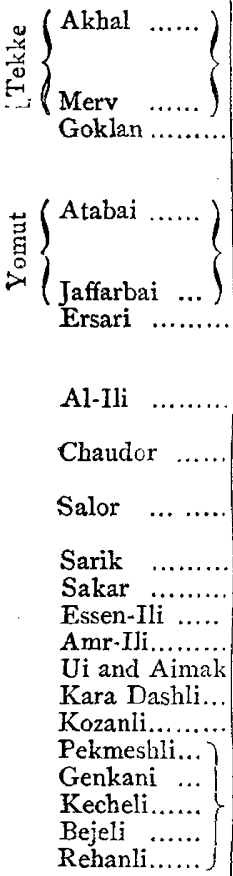 & 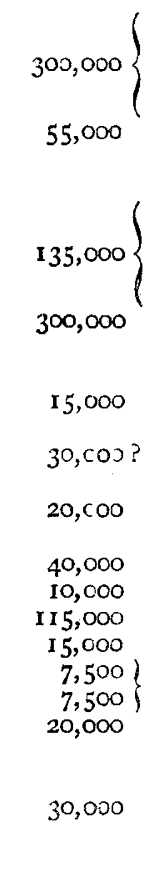 & $\begin{array}{l}\text { N. slopes Kuren-dagh and on } \\
\text { Tejend River (Lower Heri- } \\
\text { rudd). } \\
\text { Merv Oasis. } \\
\text { Upper Atrek, Gurgan, and } \\
\text { Simbur, and in Mazan- } \\
\text { deran. } \\
\text { S.E. Coast Caspian, east- } \\
\text { wards to Kizil-Arvat, and } \\
\text { on Lower Oxus below } \\
\text { Khiva. } \\
\text { Left bank Oxus, about Char- } \\
\text { jui ; hence called "Lebâb" } \\
\text { or "River" Turkomans. } \\
\text { Between Oxus and Afghan } \\
\text { frontier. } \\
\text { Ust Urt plateau, east from } \\
\text { N. end Caspian. } \\
\text { About the Murghâb between } \\
\text { Merv and Herat. } \\
\text { Merv Oasis. } \\
\text { About Sarakhs. } \\
\text { South from the Chaudor. } \\
\text { About Middle Oxus. } \\
\text { N. frontier Hazarajat. } \\
\text { Kozen Dagh (Taurus). } \\
\end{array}$ \\
\hline & $\mathrm{I}, \mathrm{I} 1 \mathrm{CO}, \infty \mathrm{O}$ & \\
\hline
\end{tabular}

The discrepancy between this estimate and that of Obrutcheff is due to the fact that in the above list are included the Turkoman nomads of Asiatic Turkey, besides a large branch of the Goklans, some 8,000 families, now settled in Mazanderan.

\section{A. H. KEANE}

\section{DISCOVERY OF A GASEOUS NEBULA}

$T$ HE Rev. T. W. Webb writes as follows to the Times last week :-

On the night of November 14, while sweeping in the constellation Cygnus with a low power on my $9^{\prime} 38$ inch silvered speculum by With, I perceived an object resembling, but not quite identical with, a bluish 9 magnitude star. The use of higher magnifiers at once detected the existence of an ill-defined bright disk, subtending about

I "Le nom de Bouroute leur est absolument inconnu" ( $\mathrm{Ch}$. de Ujfalvy in Bul. de la Soc. de Géographie for June, 1878 ).

2 In the Russian statistical work, "Sbornik," iii. p. 80. $4^{\prime \prime}$, and surrounded perhaps with a slight amount of glow. It has since been identified at other observatories as No. 4,004 in Argelander, $+4 \mathrm{I}$, the place for 1880 being R.A., 2 Ih. 2 m. 3Is.; D., $+41^{\circ} 45^{\prime} 3$. Through the kindness of Dr. Copeland, by whom it has been carefully examined under the greatest instrumental advantages at Lord Lindsay's observatory at Dunecht, North Britain, I am enabled to add the following interesting particulars. It is not circular, and has a sharp nucleus near the north-preceding edge, with a faint effusion of light in the opposite direction. Three very measurable bright lines were found in a powerful spectroscope, of which the positions, as given by two sets of measures, were respectively $500^{\circ} \mathrm{I}, 495^{\circ} 7,4^{\circ} 7^{\circ} \mathrm{O}$, and $500^{\circ} \mathrm{I}, 495^{\circ} 6,486^{\circ} \mathrm{o}$. When these values are compared with those deduced by D'Arrest from the results of several obseryers of known objects of this nature$500.4,495 \%, 486.1$ - there can be no remaining doubt that the object in question is of the very interesting and mysterious class termed planetary, or, more correctly, gaseous nebulæ. Dr. Copeland assigns 8, 5, and $I$, as the approximate intensities of these lines, reckoning from the least refrangible direction. It can occasion no surprise that its true characters should have escaped the piercing and practised gaze of Argelander, as it would require a much larger instrument than that which he employed to give any intimation of its nature.

\section{A NEW PLANETARIUM}

SIGNOR N. PERINI, of Garrick Chambers, Garrick Street, has invented a planetarium, which, so far as we are aware is in all respects superior to, more vraisemblable than, any apparatus of the kind hitherto attempted. The structure, for such it really is, consists first of a hemispherical dome, fourteen feet in diameter at the base and the same in height, resting on twelve columns. Getting underneath the dome, one sees the vault overhead coloured so as to represent the starry sky, with the milky way and the constellations in their proper places. Suspended from the top by a narrow hollow rod is an opal globe lit up by gas or electricity to represent the sun, and around this, at their proper proportional distances, are suspended by almost invisible wires, the planets from Mercury to Uranus. By a slight turn of a key Signor Perini sets the solar system in motion, when the sun revolves on its axis, and all the planets in their proper elliptical orbits and at their proper axial inclination, and with proportionate velocity. Saturn has his rings and the other planets their moons; the earth, about the size of a walnut, by a mechanism peculiar to itself, revolves on its axis at a rate accurately proportioned, the same mechanism causing the moon, a small pearl, to revolve round the earth in its own proper orbit. Round the base of the dome the various signs of the zodiac are indicated, and the paths of the planets are shown by ellipses traced around the vault. The spectator is supposed to be standing somewhere underneath the solar system, and the general effect is very striking. To us it seems the most effective method hitherto devised to convey to old or young a realistic conception of the arrangement and motions of the planets. During the working of the mechanism not a sound is heard, though above the dome, and concealed from view is an elaborate arrangement of machinery. This machinery is of the nature of clockwork, with, however, a special feature by means of which the elliptical motions of the planets are effected. Inside the earth is a watchwork arrangement, which could easily be adapted to the other planets were it not for the expense. When wound the machinery can be kept going continuously for upwards of five hours ; it can be stopped at any moment. The invention has, we believe, cost Signor Perini seven years' unremitting work and seven hundred pounds expenditure: We believe that the work has all been done 